\title{
Margaret Thatcher and Perceptions of Change in the Soviet Union
}

\author{
Archie BROWN
}

In the 1970s and well into the second half of the 1980s there was a variety of views on how change could come about in the Soviet Union and in Communist states more generally. Not everyone, though, wished even to pose that question. One widely-held assumption was that the Soviet Union was impervious to change. At a conference (in which I participated) its chairman, a retired British ambassador, summed up the proceedings by saying, to murmurs of approval from prominent members of the foreign policy communities in Britain and the United States: 'There's one thing we all know. The Soviet Union isn't going to change'. That statement was made in February 1985 - one month before Mikhail Gorbachev succeeded Konstantin Chernenko as General Secretary of the Central Committee of the Communist Party of the Soviet Union and embarked on reform of the USSR. By 1988 Gorbachev had come to the conclusion that the system needed to be fundamentally transformed. Liberalisation and, subsequently, democratisation of the Soviet system (a process that remained, however, incomplete both then and in post-Soviet Russia) were consciously pursued by Gorbachev. The break-up of the Soviet state was, in contrast, an entirely unintended consequence of the pluralisation of the political system. ${ }^{1}$

The pre-perestroika notion that the Soviet Union was largely immune to change, especially of a democratising kind, went along with a view that the most that could be achieved was to manage the relationship with the Communist world in a way which avoided crises and reduced the risk of nuclear war. It implied 'business as usual' over the long term. That outlook undoubtedly had its adherents within the British Foreign Office. Some officials there had, indeed, concluded that, since attempts at radical change in Communist countries were doomed to failure, it was foolish even to try. I recall having a very vigorous argument with two FCO exponents of such 'realism' in the early 1970s. One was a leading Foreign Office specialist on Czechoslovakia and the other, who also had a primary specialisation on East-Central Europe, went

1. For my substantiation of the points briefly made in that opening paragraph, see A. BROWN, The Gorbachev Factor, Oxford University Press, Oxford ,1996; A. BROWN, Seven Years that Changed the World: Perestroika in Perspective, Oxford University Press, Oxford, 2007; and A. BROWN, The Rise and Fall of Communism, Bodley Head, London, 2009. So far as the break-up of the Union is concerned, the continued membership within it of the Baltic republics was essentially incompatible with democratisation. However, there was nothing preordained about all fifteen union republics becoming separate states, in spite of the fact that they had institutional resources that, in the transformed political climate, they could use to pursue independence. For differing evaluations of the reasons for the dissolution of the Soviet state, see M.R. BEISSINGER, Nationalist Mobilization and the Collapse of the Soviet State, Cambridge University Press, Cambridge, 2002; V.J. BUNCE, Subversive Institutions: The Design and the Destruction of Socialism and the State, Cambridge University Press, Cambridge, 1999; and S.F. COHEN, Soviet Fates and Lost Alternatives: From Stalinism to the New Cold War, Columbia University Press, New York, 2009. 
on to become an ambassador to one of the post-Soviet states. They both argued that Gustáv Husák was greatly to be preferred to Alexander Dubček and that the current regime in Czechoslovakia was a vast improvement on the 'Prague Spring' which had been a foolhardy endeavour that had done more harm than good. The chaos of 1968 had now been replaced by a commendable stability and improved living standards.

That would not appear, however, to have been the predominant view within the FCO which contained quite a wide spectrum of opinion. Sir Rodric Braithwaite has said that he believed that 'the seeds of change were sown in the early 1960s and that the Soviet Union was bound to change from inside' but added that this, too, 'was certainly not the prevailing view' in the FCO. ${ }^{2}$ Officials often felt an affinity with those whom they regarded as the 'technocrats' in Communist countries and believed that if change was to come, it would be through them. ${ }^{3}$ In fact, when radical change came from within ruling Communist parties, whether in Czechoslovakia in 1968 or in the Soviet Union during perestroika, it was instigated by people who were interested in ideas and who were very much politicians, not technocrats. One strand of Foreign Office thinking which was much more to the point was the seeking of more East-West contact in the belief that this would contribute over the long term to a liberalisation of the regimes under Communist rule. That approach predominated in the mid-1970s and a striking manifestation of it was the seriousness with which FCO officials took the Helsinki process.

The United States administration, and Henry Kissinger specifically, were much readier to cut a deal on terms acceptable to the Soviet negotiators than were the British. Far from legitimising the political boundaries in Europe for all time, the Final Act of the Conference on Security and Cooperation in Europe (CSCE) incorporated the principle that they could be changed peacefully. It also placed an emphasis on human rights and on a free flow of information which was to prove an embarrassment to Communist rulers. ${ }^{4}$ Margaret Thatcher was among those who believed at the time that the Helsinki agreement played into the hands of the Soviet Union, although later

2. Personal communication from Rodric Braithwaite of 14 August 2009.

3. Thus, for example, Sir Duncan Wilson, who was British ambassador to Moscow from 1968 until 1971, was a relative optimist about the longer-term prospects for change in the Soviet Union, but time and again in his dispatches he places his hopes in the 'technocrats' who were contrasted with the 'ideologists'. See, for example, G. BENNETT, K.A. HAMILTON (eds.), Documents on British Policy Overseas, Series III, Vol.I: Britain and the Soviet Union, 1968-1872, HMSO, London, 1997, pp.48, 87, 160 and 304. Wilson, however, in his valedictory dispatch from Moscow in 1971 made a case for Britain following a policy towards the Soviet Union more akin to that being pursued by the West Germans and the French. In particular, he strongly approved of Willy Brandt's Ostpolitik, noting that Brandt's 'own powerfully stated justification of this policy is essentially that, in the long term, it will assist peaceful evolution in Eastern Europe (including the Soviet Union)', ibid., p.308.

4. For documentation of the British role in the CSCE process, see G. BENNETT et al (eds.), Documents on British Policy Overseas, Series III, Vol.II: The Conference on Security and Cooperation in Europe 1972-1975, HMSO, London, 1997; and for a valuable retrospective evaluation, see R. DAVY, Helsinki myths: setting the record straight on the Final Act of the CSCE, 1975, in: Cold War History, 1(2009), pp.1-22. See also S. SAVRANSKAYA, Unintended Consequences: Soviet Interests, Expectations and Reactions to the Helsinki Final Act, in: O. BANGE, G. NIEHART (eds.), Helsinki 1975 and the Transformation of Europe, Berghahn, Oxford, 2008, pp.175-190. 
she acknowledged that 'by making human rights a matter of treaty obligations rather than domestic law it gave the dissidents leverage which they employed to the full'. ${ }^{5}$ After Thatcher became Prime Minister, and especially between the Soviet invasion of Afghanistan in December 1979 and 1983, British policy was to avoid high-level contact with Soviet leaders. This reflected the views of the Prime Minister more than the attitude of the FCO. At the time of the death of Leonid Brezhnev in November 1982 the Foreign Secretary was Francis Pym whose relationship with the Prime Minister was difficult, to say the least. Pym disapproved of the fact that Mrs Thatcher had chosen not to be among the numerous heads of government who attended Brezhnev's funeral in Moscow and deplored, more generally, her resistance to the idea that there needed to be more dialogue with the Soviet Union. ${ }^{6}$

Another position, which had some adherents in the Foreign Office, although there it was only a minority view, was that Western countries should be much more aggressive in waging the Cold War against an unreformable Soviet Union, both through increased military and intelligence expenditure and by going on the ideological offensive. That was a view held less by officials than by many of Margaret Thatcher's informal advisers. Among them, Brian Crozier - who, on his own account, had numerous meetings with Thatcher, both while she was leader of the opposition and when she was Prime Minister - may serve as an extreme example. For some of those who saw themselves as Thatcher's natural allies, it was self-evident that Gorbachev's perestroika could be nothing but cosmetic and a 'grand deception'. ${ }^{7}$ Even with the benefit of hindsight, Crozier believed that 'everything Gorbachev said and did, in fact, was in line with the teaching of Lenin, his earthly god' ${ }^{8}$ A number of Thatcher's informal advisers fell into the category of those who, as Alec Nove put it in 1987, believed both that 'the Soviet Union is an expansionist monster in its very essence' and that fundamental change within the system was impossible. Therefore, 'any change that has actually occurred cannot be fundamental because it has occurred' ${ }^{9}$ It goes without saying that advisers of that cast of mind were oblivious to the single most important fact for understanding the potential for change in Communist Europe - namely, that the Communist Party of the Soviet Union contained people of the most diverse political views, to be found not only in policy-oriented research institutes but even in such an inner sanctum of the party apparatus as the International Department of the Central Committee. It was from there that Gorbachev was to draw several of the most

5. M. THATCHER, The Path to Power, HarperCollins, London, 1995, pp.349-353.

6. F. PYM, The Politics of Consent, Hamish Hamilton, London, 1984, p.60. Pym says that 'I tried to persuade the Prime Minister that Britain should rebuild a dialogue with the Soviet Union', but he failed. Following his dismissal from office, he complained about the centralisation of decision-making within the government, adding: 'This process stems from the Prime Minister's tendency to think she is always right. In turn, this leads her to believe that she can always do things better than other people, which then encourages her to try to do everything herself' (p.17).

7. B. CROZIER, The Gorbachev Phenomenon, Claridge Press, London, 1990, p.247.

8. B. CROZIER, Free Agent: The Unseen War 1941-1991, HarperCollins, London, 1993, p.289.

9. A. NOVE, in the symposium, 'What's Happening in Moscow?', in: The National Interest, 8(Summer 1987), pp.3-30, at p.18. (Nove was one of eight contributors to this early evaluation of the significance, or otherwise, of Gorbachev's reforms by that Washington journal.) 
influential 'new thinkers' of the perestroika era, including Anatoliy Chernyaev, his principal foreign policy adviser. Chernyaev became a full-time, and highly influential, aide to Gorbachev in February 1986, having been a deputy head of the International Department for the previous sixteen years. ${ }^{10}$

From the people outside government who most frequently bent Thatcher's ear on the subject of the Soviet Union in the second half of the 1970s and in the early 1980s she was unlikely to draw the conclusion that the most realistic hope of change serious change that could get off the ground - lay within the Communist Party of the Soviet Union itself. The agents of change for that circle of advisers, to the extent that they admitted even the possibility of improvement occurring, were dissident groups, religious believers and national minorities. Some of those who advised Thatcher informally on what they perceived as an acute threat of Soviet subversion reinforced her tendency to regard the Foreign Office as a nest of 'defeatists, even collaborators', in the view attributed to her by Sir Percy Cradock, her Foreign Policy adviser of the perestroika years. ${ }^{11}$ Sir Rodric Braithwaite has recalled Thatcher's reaction when it was suggested in 1980 that she might usefully acquaint herself with the knowledge of the Soviet Union of a group of FCO specialists: 'Foreign Office? Foreign Office? What do they know about Russia'? But when she took part in the discussion and learned more about the serious problems the Soviet Union was facing, she observed that if it was 'in such a parlous state, the system was bound to collapse before long'. ${ }^{12}$ In fact, it was not bound to collapse any time soon. A highly authoritarian regime, and especially one with all the sophisticated levers of propaganda, control, and repression that the Soviet system possessed, could survive economic downturn and foreign political setbacks (such as the Prague Spring of 1968 and the rise of Solidarity in 1980-81) by tightening the screws at home and within the Soviet bloc.

\section{The September 1983 Chequers Seminar}

The validity of Alexis de Tocqueville's view that the most dangerous time for an authoritarian regime is when it begins to reform itself was to be demonstrated, yet again, in the second half of the 1980s. However, among many of Thatcher's informal advisers on the USSR and Eastern Europe, the idea that a genuine reformer could emerge as leader of the Communist Party of the Soviet Union (CPSU) was ruled out of court. There is no evidence that before 1983 the British Prime Minister expected change in the Soviet Union to emanate from within the CPSU. Rodric Braithwaite,

10. Extraordinarily, as late as 1990 , Crozier leapt to the defence of the notion of a 'monolithic and unchanging Soviet system' (see B. CROZIER, The Gorbachev Phenomenon, op.cit., p.233). By that time, however, Thatcher knew very much better.

11. P. CRADOCK, In Pursuit of British Interests: Reflections on Foreign Policy under Margaret Thatcher and John Major, John Murray, London, 1997, p.24.

12. R. BRAITHWAITE, Across the Moscow River: The World Turned Upside Down, Yale University Press, London, 2002, p.51. 
in his article in this issue, quotes Thatcher saying that she spotted Gorbachev 'because I was searching for someone like him'. That was doubtless true from September 1983 onwards, but not earlier. With strong encouragement from John Coles, her Private Secretary at that time (later, as Sir John Coles, Head of the Diplomatic Service) and her Foreign Policy Adviser, Sir Anthony Parsons, Thatcher decided to convene a major seminar to re-evaluate British foreign policy, the main emphasis of which was to be on East-West relations. There was alarm within the Foreign Office that Thatcher might pack it with people whom she consulted, at Chequers and elsewhere, in her more frequent political, rather than governmental, seminars. ${ }^{13}$

Once persuaded of the desirability of this official seminar, involving the Foreign Secretary and the Secretary of State for Defence as well as outside experts, Thatcher approached it with characteristic zeal and industriousness. She read and annotated in advance of the seminar the lengthy papers prepared for the Chequers meeting by the Foreign Office and the Ministry of Defence and the shorter papers (6-8 pages each) prepared by the eight specialists from outside government whose invitations were personally approved by the Prime Minister. Just as the Foreign Office had been anxious to keep out those who, from their standpoint, were some of Thatcher's most dubious allies, she had been adamant in rejecting the names of FCO experts when they were proposed for the specialist component of the seminar. In her memoirs Thatcher says that she had wanted 'to pick the brains of experts on the Soviet Union' but 'instead of the best minds on the Soviet system' she was presented with 'a list of the best minds in the Foreign Office, which was not quite the same thing'. She added:

'The difficulty of tapping into outside thinking even in our own open democratic system of government shows just why closed totalitarian systems are so sluggish and mediocre' ${ }^{14}$

It is doubtful, though, if any post-Second World War Prime Minister consulted with outside specialists more than Thatcher did - both for better and for worse. By the time the seminar of 8-9 September 1983 went ahead, with the academics involved only on the first day, she 'felt that we did have the right people and some first-class papers'. ${ }^{15}$

13. For these unofficial seminars (many of them organised by Hugh Thomas), which had an impact on Thatcher's thinking but a diminishing one after she established a working relationship with Mikhail Gorbachev, see G.R. URBAN, Diplomacy and Disillusion at the Court of Margaret Thatcher: An Insider's View, I.B. Tauris, London, 1996. Foreign Office alarm at the prospect of the September 1983 Chequers seminar, involving outside specialists as well as ministers and officials, and FCO relief at its outcome, was reported to me shortly afterwards by Malcolm Mackintosh, the Cabinet Office specialist on the Soviet Union.

14. M. THATCHER, The Downing Street Years, HarperCollins, London, 1993, p.451.

15. I have discussed this seminar in much greater detail, citing the papers produced for it, along with Thatcher's annotations of them (obtained under the UK Freedom of Information Act) in A. BROWN, The Change to Engagement in Britain's Cold War Policy: The Origins of the Thatcher-Gorbachev Relationship, in: Journal of Cold War Studies, 3(2008), pp.3-47. 
The Prime Minister, having retained her deep suspicion of the Foreign Office (though she made exceptions for some of its individual members), ${ }^{16}$ totally ignored in her memoirs the substantial paper produced by the FCO. It came to 84 pages, 50 of which were devoted to East-West relations. There was also a section defining Britain's 'global interests and priorities', another on the Middle East, and one on the European Community. Her copious annotations of the East-West Relations FCO paper at the time are, in any event, of more historical significance than her retrospective remarks would have been. She took issue with the Foreign Office statement that 'the West is faced by the task of managing a powerful military Empire in decline'. She did not like the word 'managing' or, evidently, the statement that the Soviet Union was 'a powerful military Empire in decline'. That last phrase was double-underlined and greeted with double question-marks in both margins. ${ }^{17}$ Some of the FCO points earned large ticks, such as the statement that 'The Russians should be disabused of any impression that they can divide the West or undermine its resolve by appeals to public opinion' and that 'balanced and verifiable arms control agreements which would maintain security at lower levels of expenditure' should be pursued. She also approved of the statement that 'Nothing so far, during the Andropov period of office, has indicated a willingness to alter the fundamentals of the system'.${ }^{18}$ The FCO stress on a need to improve the flow of information to Communist countries was also met with underlinings of assent. The Prime Minister questioned, however, their statement that 'the pursuit of national ambition and the spread of communism are closely linked in the minds of Soviet leaders' ${ }^{19}$ The Foreign Office's preamble on Britain's global interests and priorities referred to 'Soviet expansion' into Afghanistan and said that

'we must ensure [...] that the Soviet Union either withdraws from the country or continues to bear the full cost of its occupation, political as well as military'. ${ }^{20}$

Thatcher underlined 'full cost of its occupation' and wrote in the margin 'We could put this up'; she also double-underlined 'military'.

The Foreign Office paper noted that the average age of the Soviet Politburo was at that time sixty-seven, but omitted any discussion of the implications of this, commenting simply on Soviet failure 'to evolve a way of handing on power or of renewing leadership' which had 'resulted in one sick man succeeding another' ${ }^{21}$ There was nothing about generational change and no mention of the name of Gorbachev. As the author of the paper on 'The Political System, Policy-Making and Leadership', written for the Chequers seminar, I did discuss Gorbachev as a likely future General Secretary, noting that he was 'the best-educated member of the Politburo and probably the

16. P. CRADOCK, op.cit., p.24.

17. Foreign and Commonwealth Office, 'East-West Relations' (prepared for Chequers Seminar, 8-9 September 1983), p.10. I have used the Cabinet Office copy of this document (obtained under the Freedom of Information Act), for it contains Thatcher's annotations and underlinings.

18. Ibid., pp.15 and 19 .

19. Ibid., p.11.

20. Foreign and Commonwealth Office, 'Foreign Policy: Britain's Global Interests and Priorities' (prepared for Chequers Seminar, 8-9 September 1983), p.3.

21. Foreign and Commonwealth Office, 'East-West Relations', p.23. 
most open-minded' and 'might well be the most hopeful choice from the point of view both of Soviet citizens and the outside world'.22 My doubt as to whether Thatcher was already looking 'for someone like' Gorbachev prior to the Chequers 8 September meeting is reinforced by the fact that she underlined none of the points in his favour which I advanced. ${ }^{23}$ It was, however, in the course of oral discussion of my paper at the Chequers seminar, in which I said more about Gorbachev, that Thatcher first raised the idea of inviting Gorbachev to Britain. Later discussion within the government centred, however, on the Foreign Office proposal that the Prime Minister should meet with Juri Andropov. ${ }^{24}$ The invitation to Gorbachev was not issued until June 1984. In the autumn of 1983, when Andropov was still General Secretary and Konstantin Chernenko Second Secretary, it would, indeed, have been premature to seek a visit from Gorbachev, but Andropov was already by then too ill to go anywhere.

Although in some respects the papers of the academics at the Chequers seminar of 8-9 September were bolder than those from within government (the scholars had less to lose than the officials), on many of the fundamentals they were in agreement. The first item in what the FCO called its Action Programme suggested that

'the Prime Minister should discuss East/West relations with President Reagan with a view to adopting as a conscious goal the objective of a "gradual evolution of the Soviet system towards a more pluralistic political and economic system" '.

The quotation was from American Secretary of State George Shultz whose desire for engagement with the Soviet Union was to prevail within the Reagan administration over the scepticism of the Pentagon and the CIA. Shultz's view was shared by Sir Geoffrey Howe and, if it had been seen by the academic specialists at the time (it became available to them only a quarter of a century later when the document was declassified), the scholars, too, would have endorsed that aim. When Thatcher asked the outside specialists after lunch at Chequers on 8 September for their policy recommendations, they emphasised 'the desirability of more contacts with Communist countries at all levels - from dissidents to General Secretaries'. ${ }^{25}$

The significance of the September 1983 Chequers seminar lay in the fact that it was the turning-point at which Thatcher was persuaded that it was desirable to seek

22. The passage is cited at greater length in A. BROWN, The Change ..., op.cit., p.13, identifying which parts of that paragraph were and were not underlined by the Prime Minister.

23. She did, however, underline many other points in the paper and also identified it (by its subjectmatter) in her memoirs as the one she had found most useful (M. THATCHER, The Downing Street Years, op.cit., p.451). This may have been partly because of the greater salience the reference to Gorbachev had for her subsequently. That the discussion of Gorbachev in the seminar stuck in Thatcher's mind is suggested by the fact that I was invited - along with three other academics and one businessman - to 10 Downing Street the evening before Mikhail Gorbachev arrived in Britain in December 1984. This informal meeting on 14 December 1984 was with the Prime Minister and Foreign Secretary. I was asked to speak specifically about Gorbachev. The other participants, who had broader assignments, were Michael Kaser, Alec Nove (both of whom had participated in the Chequers seminar), Lawrence Freedman and businessman Norman Wooding.

24. A. BROWN, The Change to Engagement ..., op.cit., pp.14 and 18-21.

25. Ibid., p.30. 
more contact with the Soviet Union and the countries of Eastern Europe. That view was advanced not only by the Foreign Secretary, Sir Geoffrey Howe, ${ }^{26}$ but also by the Secretary of State for Defence, Michael Heseltine, ${ }^{27}$ and was shared by the Minister of State at the Foreign Office responsible for relations with the Soviet Union and Eastern Europe, Malcolm Rifkind. That it was independently promoted by the outside specialists at the Chequers seminar - who were unaware of the intra-governmental communications - should normally have been inconsequential by comparison. However, given Thatcher's distrust of the Foreign Office and her difficult relationship not with the Ministry of Defence but with Heseltine personally, ${ }^{28}$ the fact that the academics produced arguments which complemented those of the FCO almost certainly mattered. That is, furthermore, suggested by the fact that from the two and a half pages of her memoirs Thatcher devotes to this seminar, a reader could be forgiven from concluding that the only people involved in the discussion were the outside specialists. ${ }^{29}$

In a memorandum dated 12 September 1983 sent to Brian Fall, who was the Private Secretary to Sir Geoffrey Howe, John Coles summarised the conclusions of the Chequers seminar, following discussion after the academics had departed. These related to "the policy which the Government should pursue on East/West relations in the next few years'. Coles noted:

'The question of whether or not the United Kingdom should seek increased contact, at higher levels, with the Soviet Union was discussed at length. It was agreed that the aim should be to build up contacts slowly over the next few years. There would be no public announcement of this change of policy'. ${ }^{30}$

It had been agreed, Coles reported, that 'the capacity of the West to exercise influence on the Soviet Union was not great' and policy should 'be based on the assumption that any change in the system in at least the medium term would not be fundamental'. Eastern Europe 'might provide more scope for influence', but the process of change there, too, 'would be at best gradual'. ${ }^{31}$

26. Cabinet Office Papers PM/83/65, Sir Geoffrey Howe, Memorandum to Prime Minister, 'Strategy Meetings on Foreign Affairs and Defence', 05.09.1983. All the Cabinet Office and Foreign Office papers cited in this article were obtained under the Freedom of Information Act.

27. Cabinet Office Papers, MO 11/9/4, Michael Heseltine, Memorandum to Prime Minister, 'Britain and Arms Control', 01-09.1983.

28. Thatcher initially tried to prevent Heseltine from attending the part of the Chequers seminar involving the academics where, in fact, he was the only person on the government side of the table to express disagreement, more than once, with the Prime Minister. Although Heseltine's memorandum of 1 September to the Prime Minister, cited in the previous note, was sent on to Thatcher by her Private Secretary John Coles with a note saying 'You will want to read this before the Chequers meetings', the text, though doubtless read by its recipient, remained unmarked by even as much as a solitary underlining.

29. M. THATCHER, The Downing Street Years, op.cit., pp.451-453.

30. Foreign Office Papers, RS013/2, John Coles letter to Brian Fall, FCO, 'Policy on East/West Relations', 12.09.1983, pp.1-4, at p.1 (italics added).

31. Ibid. 
So far as a meeting with Andropov was concerned, Coles reported that 'the Prime Minister would not go to the Soviet Union for this purpose'. The aim should, therefore, be 'to persuade Mr Andropov to visit the West (which he had never done)'. 32 Furthermore:

'It might also be useful to arrange at the appropriate time for other senior members of the Politbureau, particularly potential successors to Andropov, to visit London. The Prime Minister would be prepared, in principle, to receive one or more such visitors. This question should be further examined in due course'. ${ }^{33}$

\section{Gorbachev's 1984 Visit to Britain}

A little over a fortnight after the Chequers seminar of 8-9 September Thatcher had her interest in meeting Gorbachev augmented. On a visit to Canada, she met with Prime Minister Pierre Trudeau and discussed international affairs with him. What, she said, "was most interesting for me was his impression of Mikhail Gorbachev, of whom I had heard but whom I did not yet know'. Gorbachev, it seemed, had 'been prepared to argue and make at least verbal concessions'. Nevertheless, Thatcher adds: 'I did not at this time foresee the importance of Mr Gorbachev for the future'. ${ }^{34}$

In September 1983 (and for some time thereafter), the expectation of Thatcher as well as of the Foreign Office was that the best that could be hoped for was gradual change in the Soviet Union and Eastern Europe, but that a policy of engagement with these countries should be adopted. So far as Eastern Europe was concerned, 'each country should be treated individually and those tendencies which diverged from the Soviet model should be encouraged'. ${ }^{35}$

Andropov died in February 1984 and was succeeded by Konstantin Chernenko whose health was already in serious decline. Gorbachev became - after some argument and delaying tactics - Second Secretary of the CPSU. The largely ceremonial post of Chairman of the Foreign Affairs Commission of the Soviet of the Union of the Supreme Soviet of the USSR went with that job. It was in his Supreme Soviet capacity that Gorbachev was invited by the Chairman of the Foreign Affairs Committee of the House of Commons, Sir Anthony Kershaw, to come to Britain in December 1984. A more general British letter of invitation (signed by the Speaker of the House of Commons and the Lord Chancellor) to the Supreme Soviet to send a delegation had been issued on 2 February (while Andropov was still alive), but it expressed no preference as to its composition or leadership. In contrast, the letter delivered by the British Ambassador to Moscow on 14 June, in Kershaw's name but drafted in the Foreign Office under the supervision of Malcolm Rifkind, the Minister

\footnotetext{
32. Ibid., p.2.

33. Ibid.

34. M. THATCHER, The Downing Street Years, op.cit., p.321.

35. John Coles, 'Policy on East/West Relations', p.3.
} 
of State with special responsibility for British relations with the Soviet Union and Eastern Europe, was addressed to Gorbachev. It made no bones about the fact that 'I should like to invite you to lead the delegation from the Supreme Soviet'. The British Ambassador, Sir Iain Sutherland, was instructed by Sir Geoffrey Howe to make clear to Gorbachev that he would be received by the Prime Minister. ${ }^{36}$

Gorbachev's visit to Britain in December 1984 is discussed elsewhere. ${ }^{37}$ It was significant for Gorbachev, since he did not put a foot wrong and thus improved his already strong position as principal contender to succeed Chernenko as Soviet leader. And it was important for Thatcher, since she established a good relationship with Gorbachev in advance of his becoming General Secretary. The fact that she was the foreign leader to whom President Ronald Reagan felt closest, and one whose opinion he took seriously, meant that her judgement counted for something in Washington. That was especially significant in the year that separated Gorbachev's UK visit and Reagan's first summit meeting with Gorbachev in Geneva. Thatcher promptly conveyed the favourable impression Gorbachev had made on her when she participated in a meeting at Camp David with President Reagan and some of his most senior officials on 22 December 1984. The Prime Minister told them that Gorbachev was 'an unusual Russian' in that he 'was much less constrained, more charming, open to discussion and debate, and did not stick to prepared notes'. ${ }^{38}$ She made it clear to her American hosts that she had not been a soft touch. The transcript of the Camp David meeting reports: 'Over the private lunch at Chequers, she had raised a number of pointed questions. She asked Gorbachev why the Soviet Union denies its people the right to emigrate. She had underlined that the West simply cannot understand or accept the Soviet policy of refusing people the right to leave. She contrasted the Soviet policy with the situation in the West, where many countries have had to stop people from coming in'. 39

\section{7 - A Year of Changing Perceptions}

From her meetings with Gorbachev in December 1984 and on the occasion of Chernenko's funeral in March 1985, Thatcher was already disposed to think well of him. That does not mean that she had yet reached the conclusion that serious change in the Soviet Union might be in the offing. The issue of how radical Soviet reform might be in the process of becoming was the central theme of another Chequers seminar

36. The process by which the invitation to Gorbachev was issued is discussed in greater detail in A. BROWN, The Change ..., op.cit., esp. pp.18-22.

37. By R. BRAITHWAITE, A. GRACHEV in this issue and in A. BROWN, The Change ..., op.cit., esp.pp. 31-35.

38. '1984 Dec 22. Cold War: Thatcher-Reagan Meeting at Camp David' (declassified document in the Reagan Library), available on Thatcher Foundation website: http:www.margaretthatcher.org/ archive/displaydocument.asp?docid $=109185$.

39. Ibid. 
which the Prime Minister convened in February 1987, in preparation for her official visit to the Soviet Union for extended talks the following month. Most of the academics present with expertise on the Soviet Union, as well as the British Ambassador to Moscow at the time, Sir Bryan Cartledge, took the view that serious reform was underway and that it could turn out to be far-reaching. Charles Powell, who had succeeded John Coles as the Prime Minister's Private Secretary in the middle of 1984, noted the division of opinion at the seminar:

'Discussion of the prospects for change within the Soviet Union revealed a difference between those, principally the experts on the Soviet Union, who were impressed by the scope and energy of Gorbachev's reforms; and those, principally non-specialists, who were not convinced that real change could be either possible or allowed and were sceptical of Gorbachev's motives. To simplify: between enthusiasts and sceptics' ${ }^{40}$

In a covering letter to A.C. Galsworthy in the Foreign Office, Powell said that his account 'may err slightly on the side of conveying too negative a view of what is happening in the Soviet Union'. It was, indeed, very much closer to the view of the sceptics, and a number of conclusions which Powell listed as having commanded 'broad assent' did not reflect the view of a majority of academic specialists present (of whom I was one). These included the proposition that 'fundamental change was not on the agenda' and that there might be enough reform to 'produce limited improvements in efficiency', but 'there would be nothing dramatic or far-reaching'. Indeed, 'The Soviet system might at best evolve in 20 years time into something resembling Yugoslavia today' (italics added). ${ }^{41}$ An annotation by an FCO official to the covering letter which circulated Charles Powell's report to a small group of officials cites Martin Nicholson, the Cabinet Office specialist on the Soviet Union who participated in the seminar, listing as the 'Enthusiasts: [Ronald] Amann, [Peter] Frank, [Archie] Brown, [Sir Bryan] Cartledge' and as 'Sceptics' Robert Conquest and Sir Michael Howard. (Although this was not mentioned in the Foreign Office annotation, the most sceptical contributor to the discussion was, in fact, Hugh (Lord) Thomas, a longstanding political ally and speechwriter of the Prime Minister). When Thatcher had said she wanted an American specialist on the Soviet Union at the seminar, the Foreign Office had chosen Seweryn Bialer of Columbia University. His views were to the taste of the FCO. It was noted that, in his oral contributions to the seminar, Bialer, in contrast with the 'enthusiasts' and the 'sceptics', occupied 'the judicious centre ground'. ${ }^{42}$

40. Cabinet Office Papers A 2162 (Revise), Report by Charles Powell, 01.03.1987, 'Seminar on the Soviet Union', p.1.

41. Ibid.

42. A. BROWN, The Change ..., op.cit., p.38. I am not convinced that Conquest's and Howard's positions at the seminar were as sceptical as Thomas's or Cradock's. Conquest's view at that stage of perestroika may be judged from a remark in an article he wrote at the time saying 'Gorbachev stands for radical reforms within the system - that is, reforms which are not really radical' (italics in original). See R. CONQUEST, What's Happening in Moscow?, in: The National Interest, 8(Summer 1987), pp.3-6, at p.5. This article was in the same symposium as A. NOVE's article, already cited, in which Nove spoke of observers who had decided that the reforms could not be fundamental because they were happening. 
Thatcher had, however, heard for herself a variety of different viewpoints at the seminar, even though the view that nothing 'far-reaching' could be expected was evidently shared at that time by both her principal aides - her Private Secretary (Powell) and her Foreign Policy Adviser, Sir Percy Cradock. She had also read a number of articles containing a wide spectrum of opinion on developments in the Soviet Union, as well as Gorbachev's speeches, before departing for Moscow. If, as seems likely, Thatcher was still not entirely sure on the eve of her first extended visit to the Soviet Union as Prime Minister whether she was primarily with the 'sceptics' or the 'enthusiasts', she returned as an enthusiast, in the sense that she had been persuaded that highly significant change was taking place and that Gorbachev was serious about carrying the reform process further. The two leaders argued at length - on arms control, especially nuclear weapons, and on Third World hotspots - but the Prime Minister welcomed the steps Gorbachev was taking domestically. In particular, Thatcher referred in their conversation to Gorbachev's report to the January 1987 plenum of the Central Committee of the CPSU, at which he had put political reform firmly on the agenda, as a 'historic speech'. ${ }^{43}$

She was also influenced by the variety of opinion she heard expressed in different parts of the Soviet Union and by the fact that she was given the opportunity of a live television interview to come out on top in debate with her interlocutors. Although these were still early days of perestroika, and the system was to become far more pluralistic by the end of the 1980s than it was in March 1987, it was already a far cry from Brezhnev's Soviet Union. The difference was not lost on the British Prime Minister. At the next meeting between the two leaders, at Brize Norton on 7 December 1987, when Gorbachev made a stopover in Britain on his way to the Washington summit meeting with President Reagan, the tone of their exchanges was even warmer than before. (The television cameras captured the atmosphere. As a smiling and windswept Thatcher watched Gorbachev coming down the steps of his aircraft, some irreverent observers were reminded of the film Casablanca.)

Thatcher congratulated Gorbachev on his 'bestseller', Perestroika: New Thinking for Our Country and the World, which she had read, and Gorbachev apologised for not having a copy with him which he could sign for her! ${ }^{44}$ Both leaders noted that their relations had become much closer which Thatcher attributed 'in the final analysis' to the policies Gorbachev had pursued both domestically and internationally. Distrust, she said, was gradually disappearing and the great significance of perestroika was being recognised. ${ }^{45}$ Gorbachev spoke still more frankly than hitherto, given that his conversation was with the person whom the pre-perestroika Soviet press had

43. Gorbachev Foundation Archives, 'Zapis' peregovorov M.S. Gorbacheva s prem'er-ministrom Velikobritanii M. Tetcher, 30 marta 1987 goda', p.37. The citation is from the 64-page document of the Thatcher-Gorbachev discussions of two days earlier produced by Anatoliy Chernyaev on 1 April 1987.

44. Gorbachev Foundation Archives, 'Zapis' besedy M.S. Gorbacheva s prem'er-ministrom Velikobritanii M. Tetcher, 7 dekabrya 1987 goda', pp.1-2. This 18-page document is the Soviet transcript of the Thatcher-Gorbachev discussions at Brize Norton airport.

45. Ibid., p.2. 
dubbed the 'Iron Lady'. He said 'the fact is that up to the present we have not been able to cross the threshold beyond the Stalinist system of administrative government'. ${ }^{46}$ The boldest attempt thus far to change things had been made by Nikita Khrushchev and there had been some half-measures in Brezhnev's time, but now something completely different was being undertaken. It was a policy of 'democratisation, glasnost and economic transformation, including the decentralisation of the economy', but every step had to be calculated carefully. ${ }^{47}$

Thatcher by now was identifying very strongly with Gorbachev as a reformer and comparing her own reforms (which she said had met a lot of opposition before the advantages had time to emerge) with Gorbachev's. When the Soviet leader said that his most difficult opposition was 'the old psychology', the Prime Minister said she understood him completely, adding that her kind of Conservatism was completely different from the conservatism he encountered in the Soviet Union. ${ }^{48}$ When Gorbachev volunteered that there was not a unity of views on all questions 'even in our Politburo', Thatcher responded that the same was true of the British Cabinet. ${ }^{49}$ The leaders were two-thirds of the way through their friendly conversation before the first note of discord arrived when nuclear weapons entered the discussion. Thatcher continued to argue for them as a deterrent, not a weapon, insisting that the nuclear bomb had 'already kept the peace in Europe for more than forty years'. Gorbachev reiterated his concern about the proliferation of nuclear weapons and wanted to know when Britain would be ready to take part in the process of nuclear disarmament. ${ }^{50}$ The Prime Minister also raised the issue of Afghanistan, to which Gorbachev responded that the political decision about ending the Soviet military presence in Afghanistan had already been taken and that the sooner 'your American allies' end their interference there, 'the sooner that problem will be resolved'. ${ }^{51}$

The Brize Norton meeting ended on a very amicable note with Thatcher regretting that their meeting had been so short, asking Gorbachev to let her know the results of his meeting with Reagan, either through the Soviet Ambassador or by some other means, and repeating an invitation to him to make an official visit to Britain. Gorbachev said he would certainly pass on the information about his visit to the United States, adding: 'Then you may compare it with what your American friends say'. He thanked her for 'the reminder about my visit to England', an invitation which he would without fail take up. ${ }^{52}$

\footnotetext{
46. Ibid., p.3.

47. Ibid.

48. Ibid., p.4.

49. Ibid., p.8.

50. Ibid., pp.11-14.

51. Ibid., p.17.

52. Ibid., p.18.
} 


\section{Some Conclusions}

Following her visit to the Soviet Union in March 1987, Thatcher was in no doubt that Gorbachev's perestroika was in the interests both of the peoples of the Soviet Union and of the West. As Andrei Grachev notes in his article in this issue, she was initially more enthusiastic about the domestic reforms he had initiated than about Soviet foreign policy. It took time to convince her that it was changing dramatically. By 1989 it was clear to all but the most dim-witted or ideologically hidebound that Soviet policy towards the outside world had, indeed, been transformed. Thatcher became increasingly concerned about the strength of the opposition to Gorbachev from various quarters in the Soviet Union - by 1989 it included such major institutions as the military, the KGB, the industrial ministries and even the party apparatus - and by 1991, when she was out of office, she was, as both Grachev and Braithwaite have noted, critical that Western leaders had not done more to sustain Gorbachev. Although there were limits to what Gorbachev could get away with - as the August coup of 1991 demonstrated - the powers of the office of General Secretary, together with the existence of a constituency for radical change within the party intelligentsia and a minority of officials in the Central Committee apparatus, had enabled a break with the past. The change was fundamental - and it had occurred!

By the last two and a half years of perestroika, this was no longer a reform or revolution from above. The pluralisation of Soviet politics had produced the possibility and reality of movement from below, of which the national movements were the most destructive of Gorbachev's authority and, ultimately, of the Soviet Union itself. That point would not have been reached, however, but for the developing freedom of speech and publication and the contested elections which had already been facilitated and promoted by Gorbachev and his most radically reformist allies (including, especially notably, Alexander Yakovlev). By her support for Gorbachev and the process of perestroika, Thatcher had come to accept that far-reaching change in the Soviet Union (with its huge implications for the whole of Eastern Europe) could emanate from the highest echelon of the Communist Party in Moscow. This was far from being something that was bound to happen, but it was the only way in which fundamental change had been likely to get off the ground. It was not a possibility that had been entertained by the Prime Minister's most regular informal political advisers on Communism and the Soviet Union. ${ }^{53}$ Like her friend Ronald Reagan, however, Margaret Thatcher proved flexible enough to modify at least some of her long-cherished beliefs when brought into contact with new realities and a new Soviet interlocutor in the shape of Gorbachev.

53. See G.R. URBAN, op.cit.; and B. CROZIER, Free Agent ..., op.cit. 


\title{
Gorbachev and Thatcher
}

\author{
Witness Remarks
}

\section{Rodic BRAITHWAITE}

Thatcher played a significant but limited role in East-West relations in the last decade of the Soviet Union. She had her own vision of how East-West relations should be shaped. ${ }^{1}$ She was not prepared to accept the status quo, and she was one of the first Western politicians to give public support for liberal change in Eastern Europe. In the 1980s she played an important role in reopening up communications with the Soviet Union at a time when they were in difficulty. But the serious negotiation of change was conducted not by her, but by the American President and the German Chancellor. $^{2}$

\section{Thatcher comes to power}

In the late 1970s detente between the Soviet Union and the West began to unravel, and tension increased markedly. This was the dominating thought in Thatcher's mind when she became Prime Minister in May 1979. She believed that the balance of power between East and West had been seriously altered by the Soviet military build-up and the failure of the West, and especially Britain, to match it. ${ }^{3}$

1. Sir Rodric Braithwaite is a writer and former British Ambassador in Moscow during the fall of the Soviet Union (1988-1992). His diplomatic career included posts in Jakarta, Warsaw, Moscow, Rome, Brussels (European Union) and Washington and a number of positions at the Foreign and Commonwealth Office. He was Prime Minister's foreign policy adviser and Chairman of the Joint Intelligence Committee (1992/93), was awarded the GCMG in 1994 and knighted in 1988. Braithwaite was a Visiting Fellow at All Souls College, Oxford in 1972-73 and at the Wilson Center in Washington in 2005. Among his publications: Engaging Russia: A Report to the Trilateral Commission, with Robert Blackwill and Akihiko Tanaka (1995); Russia in Europe (1999); Across the Moscow River: The World Turned Upside Down and Moscow 1941: A City and Its People at War (2003); Moscow 1941: A City and its People at War (2006). His forthcoming book: Afgantsy: The Russians in Afghanistan, will be published in 2011.

2. This paper is based on my personal diary, on the published memoirs of the two protagonists and other publications, on published Russian documents of proceedings in the Politburo and elsewhere, and on conversations with Gorbachev's associates and some material generously supplied by them. I have mostly used the English translations of books originally in Russian where these are available. The FCO kindly gave me permission to look through relevant documents to check my recollection of the period. The papers show that the British government was very well informed about what was going on in the Soviet Union at that time. Its judgements can bear the critical eye of hindsight. Much of that insight was due to the FCO's cadre of Soviet research experts, whose contributions over many years stand out for their clarity, knowledge and wisdom.

3. Speech by Francis Pym, shadow Defence Secretary, a few weeks before the election. 